\title{
Sediment-water column oxygen and nutrient fluxes in nearshore environments of the lower Delmarva Peninsula, USA
}

\author{
William G. Reay ${ }^{1}$, Daniel L. Gallagher ${ }^{1}$, George M. Simmons $\mathrm{Jr}^{2}$ \\ ${ }^{1}$ Department of Civil Engineering, ${ }^{2}$ Department of Biology, Virginia Polytechnic Institute and State University, \\ Blacksburg, Virginia 24061, USA
}

\begin{abstract}
Sediment-water column exchanges of oxygen, dissolved inorganic nitrogen (DIN) and dissolved inorganic phosphorus (DIP) were measured in situ over an annual cycle for sandy and silt-clay sediment types in a shallow Chesapeake Bay (USA) inlet. Benthic oxygen and inorganic nutrient fluxes differed between sediment types. Based on metabolic rate estimates and photosynthetic pigment concentrations, nearshore sandy sediments were more productive than silt-clay sediments. Overall benthic community respiration rates were $872 \mu \mathrm{mol} \mathrm{m}^{-2} \mathrm{~h}^{-1}$ for sandy sediments and $2220 \mu \mathrm{mol} \mathrm{m}^{-2} \mathrm{~h}^{-1}$ for siltclay sediments. Elevated ammonium and DIP sediment fluxes were associated with silt-clay sediments. Sandy and silt-clay sediment ammonium fluxes ranged from -44 to 358 and -30 to $615 \mu \mathrm{mol} \mathrm{m}^{-2} \mathrm{~h}^{-1}$, respectively, with DIP fluxes ranging from -5.3 to 42.0 and -3.3 to $35.7 \mu \mathrm{mol} \mathrm{m} \mathrm{m}^{-2} \mathrm{~h}^{-1}$ Negative nutrient flux values denote sediment uptake. Sediment ammonium and DIP fluxes were dependent on benthic aerobic respiration rates for silt-clay sediments. In contrast, sandy sediment ammonium fluxes were less dependent and DIP fluxes showed no relationship to benthic aerobic respiration rates. Ammonium and DIP flux rates were significantly reduced in transparent chambers as compared to opaque chambers indicating the importance of the benthic microalgal community. On an annual basis, sandy sediments could supply $11 \%$ of the phosphorus and $6 \%$ of the phytoplankton nitrogen requirements based on gross productivity estimates, whereas silt-clay sediments could supply 11 and $14 \%$, respectively. Positive correlations between sandy and silt-clay sediment DIN fluxes and phytoplankton DIN assimilatory demands emphasize the importance and interdependence of sediment heterotrophic and water column autotrophic processes. Short water column DIN and DIP turnover times, on the order of hours, were characteristic of summer conditions when water column nutrient concentrations were low and silt-clay sediment nutrient fluxes high. Conversely, nutrient turnover times on the order of days were characteristic of winter conditions when water column nutrient concentrations were high and sediment nutrient fluxes low.
\end{abstract}

KEY WORDS: Sediment-surface water interactions - Nutrients - Oxygen - Benthic microalgae Estuaries . Chesapeake Bay

\section{INTRODUCTION}

Sediment and water column interactions are of significant ecological importance to shallow coastal waters, including the Chesapeake Bay (USA) and its tidal tributaries. The significance of these interactions has been demonstrated in terms of both nutrient and oxygen dynamics (Zeitzschel 1979, Garber 1987). While considerable work regarding sediment-water column solute exchanges has been conducted in the Chesapeake Bay system, relatively few studies have focused on the shallow nearshore regions (Simon 1988,
Rizzo 1990, Simmons et al. 1992). The Bay side tidal creeks and inlets of the lower Delmarva Peninsula are characterized by narrow channels, with maximum depths varying from 3 to $5 \mathrm{~m}$, flanked by relatively broad shoal areas. Rooted vegetation, in particular eelgrass Zostera marina occurs in localized regions but is not generally widespread.

In addition to differences in hydrophysical and geochemical processes which can influence oxygen and nutrient exchange between sediments and the water column, the importance of biologically mediated processes can be expected to vary between shallow 
nearshore and deeper offshore environments. While microbial metabolism is dominated by heterotrophic activity in deeper aphotic regions, a variety of shallow water habitats support sizable benthic microalgal communities which significantly influence the productivity and nutrient dynamics of the system (Joint 1978, Propp et al. 1980, Rizzo 1990, Pinckney \& Zingmark 1993). Murray (1983) and Rizzo (1986) suggested that primary production by benthic microalgal communities approximates phytoplankton production on a squaremeter basis in the Chesapeake Bay.

Given the importance of the shallow water environments, in terms of both estuarine ecology and regional economics, information regarding all aspects of nutrient dynamics is essential for proper water quality management. As a consequence of their shallowness, a strong linkage between benthic and pelagic processes would be expected within these systems. The specific research objectives of this study were to measure sediment oxygen and inorganic nutrient fluxes for 2 nearshore sediment types, to examine the influence of benthic micro-communities on nutrient exchange across the sediment-water interface, and to evaluate the potential importance of sediment nutrient fluxes in terms of phytoplankton nutrient assimilation demands. This research should have regional applicability to tidal creek systems located on the Bay side of the Delmarva Peninsula and likewise to shallow ecosystems around the world.

\section{MATERIALS AND METHODS}

Study site. Research was conducted in Cherrystone Inlet, approximately $6.0 \mathrm{~km}^{2}$ in area, located on the Chesapeake Bay side of the southern Delmarva Peninsula (Fig. 1). Bathymetrically, the inlet is representative of Bay side inlets, with narrow channels flanked by broad shoal regions. Maximum depth within the main channel was on the order of $4 \mathrm{~m}$ and the nearshore and tidal creek regions displayed mean depths of $1 \mathrm{~m}$ or less. Cherrystone Inlet receives freshwater input from numerous tidal creeks and has direct water exchange with the Chesapeake Bay. Mean semidiurnal tidal range was $0.7 \mathrm{~m}$ with spring ranges of $0.85 \mathrm{~m}$ (NOAA 1990). Salinity and temperature exhibited seasonal patterns ranging from 14 to $23 \%$ and 0 to $32^{\circ} \mathrm{C}$, respectively. The photic zone, defined as the depth at which $1 \%$ of surface radiation remains, varied from $0.7 \mathrm{~m}$ in the summer to $6.1 \mathrm{~m}$ during winter months of the study period. Intertidal and nearshore sediments within Cherrystone Inlet were predominantly sandy substrates, whereas sediments in the more protected coves and upper creek reaches were dominated by finer grained sediments. Deeper main stem channel regions

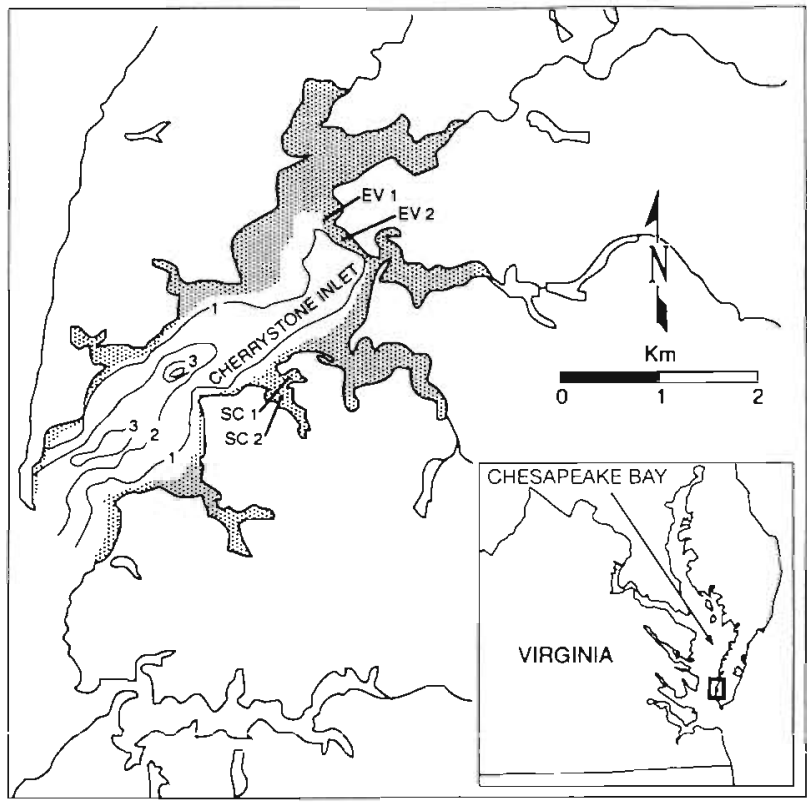

Fig. 1. Map of Cherrystone Inlet, Chesapeake Bay, USA, showing study site locations (EV 1 and 2, SC 1 and 2). Depth contours display mean tide conditions determined from the NOAA Chesapeake Bay-Cape Charles to Wolf Trap Coast and Geodetic Survey Map and corrected for local tidal variations. Depth contours (m) generated by Systat version 5.0 (Systat, Inc., Evanston, IL, USA). Shaded areas: sediments within the photic zone during summer 1990 conditions

were represented by both silt-clay and sandy sediment types. Four sampling stations (EV 1 and 2, SC 1 and 2) were selected for this study (Fig. 1), 2 for each predominant sediment type. Sampling sites were located 20 to $30 \mathrm{~m}$ offshore where mean water depths were on the order of $1 \mathrm{~m}$. Sampling stations were only periodically exposed during extreme low water events and therefore were considered as subtidal. No rooted vascular plants or macroalgae occurred at the study sites.

Physical sediment properties. Surficial (upper $20 \mathrm{~cm}$ ) sediment properties were determined on replicate $(\mathrm{N}=6$ or 7 ) cores $(4.5 \mathrm{~cm}$ i.d.) at $1 \mathrm{~cm}$ depth intervals at each study site. Grain size mass ratios were determined by wet sieving and pipet analysis (Folk 1980). Dry bulk density was determined by ovendrying samples at $105^{\circ} \mathrm{C}$ to a constant weight and expressed as dried mass per field condition volume. Sediment porosity was determined by weighing saturated samples followed by oven-drying samples at $105^{\circ} \mathrm{C}$ to a constant weight and expressed as weight loss of saturated samples per field condition volume. Percentage organic matter was determined by weight loss of dried samples following combustion at $550^{\circ} \mathrm{C}$.

In situ sediment solute flux measurements. Sediment solute flux measurements were conducted between May 1990 and April 1991. Measurements 
were conducted in the early afternoon and under similar tidal conditions in order to minimize variations between sampling periods associated with these environmental parameters. Dissolved oxygen and inorganic nutrient exchanges between the sediment and the overlying water were measured in situ using light (transparent) and dark (opaque) plexiglass hemisphere chambers (volume $7.2 \mathrm{l}$, area $0.07 \mathrm{~m}^{2}$ ). Chamber bottoms were fitted with a sharpened rim that ensured a watertight seal and uniform water volume within the chambers. Chambers were fitted with a collapsible bladder in order to account for volume changes due to potential subaqueous seepage.

In order to avoid anoxic stratification and allow for the collection of a representative sample, water was gently recirculated in the flux chambers. Water recirculation, controlled by surface mounted peristaltic pumps (total tygon tube volume $=100 \mathrm{ml}$ ) and a programmable Grasslin Digital $127-9$ clock, occurred at 15 min intervals. Water was withdrawn from the center of the chamber and redistributed back to the chamber at 2 locations to facilitate mixing and reduce input water pressures. Visual observation of transparent chambers did not indicate any disturbance to the sediment-water interface. Following flux chamber deployment and the initial water recirculation period, a $50 \mathrm{ml}$ sample volume was taken by syringe at a 3 -way valve located near the peristaltic pumps. After a 3 to $4 \mathrm{~h}$ incubation period and the final water recirculation period, a second $50 \mathrm{ml}$ sample was taken. Light and dark bottles were incubated concurrently in order to correct for water column biotic effects. Net sediment-water column solute fluxes were calculated according to the following formula which accounted for pelagic influences and volume changes due to seepage:

$$
F_{b}=\frac{\left(C_{i} V_{1}\right)-\left(C_{0} V_{0}\right)-\left[\left(B_{1}-B_{0}\right) V_{i}\right]}{T A}
$$

where $F_{b}=$ bulk sediment solute flux $\left(\mu \mathrm{mol} \mathrm{m}^{-2} \mathrm{~h}^{-1}\right), C_{j}$, $C_{0}=$ solute concentration within chamber at time $i$ and 0 , respectively $\left(\mu \mathrm{mol} \mathrm{l} \mathrm{l}^{-1}\right.$ ), $B_{i}, B_{0}=$ solute concentration within blank bottle at time $i$ and 0 , respectively ( $\mu$ mol $\left.1^{-1}\right), V_{1}, V_{0}=$ volume of water within chamber system at time $i$ and 0 , respectively (l), $T=$ time interval (h), $A=$ sediment surface area enclosed by chamber $\left(\mathrm{m}^{2}\right)$. Positive values denote a net release of solutes from the sediments, whereas negative values indicate net uptake by the sediments.

Water column productivity and photosynthetic pigments. Estimates of nearshore water column primary productivity and respiration were determined using the oxygen light-dark bottle method (APHA 1989, Method $10200-J$ ). Replicate water column samples ( $N=3$ to 6 ) were suspended in the upper $0.5 \mathrm{~m}$ of the water column on rafts designed to minimize shading effects. Water column productivity studies were conducted in concert with sediment nutrient flux studies. Estimates of daily averaged gross productivity were calculated from midday incubations, assuming photosynthetic oxygen production was distributed sinusoidally over the photoperiod (Thomann \& Mueller 1987). Daily photoperiods were determined from sunrise/sunset data (The World Almanac 1990/1991) following corrections for latitude and standard time meridian. Gross productivity was expressed in carbon equivalents assuming a photosynthetic quotient of 1.2 (Wetzel \& Likens 1991) and areal estimates assumed an average water depth of $1 \mathrm{~m}$. Total chlorophyll a (chl a) concentrations, used as a measure of microalgal biomass, were determined on replicate ( $N=3$ or 4 ) water column samples. Benthic total chl a and phaeopigment concentrations were determined on the top $1 \mathrm{~cm}$ of replicate $(\mathrm{N}=4$ to 9 ) manually collected cores $(4.45 \mathrm{~cm}$ i.d.).

Analysis. Inorganic nutrient samples were filtered with $0.45 \mu \mathrm{m}$ membrane filters. Ammonium $\left(\mathrm{NH}_{4}{ }^{+}\right)$ was determined by a phenate method (Strickland \& Parsons 1972). Nitrite $\left(\mathrm{NO}_{2}{ }^{-}\right)$was determined by diazotizing with sulfanilamide coupling with $\mathrm{N}$-(1naphthyl)-ethylenediamine to form an azo dye (U.S EPA 1983, Method 354.1). Nitrate $\left(\mathrm{NO}_{3}{ }^{-}\right)$was determined after reduction to nitrite by use of $\mathrm{Cu}-\mathrm{Cd}$ columns (U.S. EPA 1983, Method 353.1). Total dissolved inorganic nitrogen (DIN) was calculated as the sum of $\mathrm{NH}_{4}{ }^{+}, \mathrm{NO}_{3}{ }^{-}$and $\mathrm{NO}_{2}{ }^{-}$. Dissolved inorganic phosphorus (DIP) was determined by a single combined reagent ascorbic acid method (U.S. EPA 1983 Method 365.2). Dissolved oxygen was determined by an azide modification of the standard iodometric method (APHA 1989, Method 4500-O). Total chl a concentrations were determined by an alkaline acetone $190 \% \mathrm{v} / \mathrm{v}$ with water) extraction procedure and use of trichromatic equations described by Parsons et al (1984). Phaeopigment concentrations were determined by adding $0.1 \mathrm{ml}$ of dilute $(10 \%)$ hydrochloric acid to chl a samples followed by light extinction readings at 665 and $750 \mathrm{~nm}$ (Parsons et al. 1984). Functional chl a was determined as the difference between total chl a and phaeopigment concentrations. Temperature was measured to the nearest $0.1^{\circ} \mathrm{C}$ with a calibrated (NIST specifications) long-stem thermometer.

\section{RESULTS}

\section{Physical sediment properties}

Descriptive statistics of nearshore sediment properties by sampling station are given in Table 1. Sand sized particles comprised $96 \%$ of the sediment's mass at the EV sampling locations, while silt-clay sized particles constituted greater than $77 \%$ of the sediment's 
Table 1. Sediment characteristics for nearshore study sites (standard error of the mean and sample size in parentheses)

\begin{tabular}{|lcrrr|}
\hline Sediment property & EV 1 & EV 2 & SC 1 & SC 2 \\
\hline \% Gravel & $0.0(0.0,24)$ & $0.0(0.0,24)$ & $0.0(0.0,24)$ & $0.0(0.0,24)$ \\
$\%$ Sand & $95.6(0.5,24)$ & $96.0(0.3,24)$ & $23.0(2.0,24)$ & $9.5(1.1,24)$ \\
$\%$ Silt & $2.4(0.5,24)$ & $2.0(0.1,24)$ & $53.9(1.8,24)$ & $59.9(1.5,24)$ \\
\% Clay & $2.0(0.3,24)$ & $2.0(0.3,24)$ & $23.0(1.0,24)$ & $30.7(1.8,24)$ \\
Bulk density $\left(\mathrm{g} \mathrm{cm}^{-3}\right)$ & $1.74(0.03,75)$ & $1.56(0.03,69)$ & $0.71(0.03,76)$ & $0.54(0.01,79)$ \\
Porosity & $0.49(0.01,75)$ & $0.42(0.01,69)$ & $0.81(0.01,75)$ & $0.86(0.01,79)$ \\
\% Organic matter & $0.8(0.1,75)$ & $0.7(0.1,68)$ & $4.2(0.2,76)$ & $5.2(0.1,79)$ \\
\hline
\end{tabular}

mass at the SC sampling locations. Organic matter contents of the silt-clay sediments were approximately 7 times ( 4.7 vs $0.7 \%$ ) that measured in the sandy sediments. Mean porosity and dry bulk density for the sandy sediments were 0.46 and $1.65 \mathrm{~g} \mathrm{~cm}^{-3}$, respectively, and 0.84 and $0.63 \mathrm{~g} \mathrm{~cm}^{-3}$ for the silt-clay sediments. Vertical heterogeneity of sediment properties was detected where porosity and percentage organic matter decreased with depth and dry bulk density increased for both sediment types.

\section{In situ sediment solute flux measurements}

Descriptive statistics of dissolved oxygen and inorganic nutrient exchanges between the sediment and the overlying water column, by sampling period and chamber treatment, are given in Tables $2 \& 3$. Seasonal and annual estimates of sediment nutrient flux are presented in Table 4. Water column temperatures varied from 6.5 to $32.4^{\circ} \mathrm{C}$ over the study period. Sediment oxygen fluxes in light chambers provided a measure of benthic net community production (NCP) plus inorganic chemical oxidation, whereas dark chambers provided a measure of benthic community aerobic respiration and inorganic chemical oxidation. Initial water samples within and outside the chambers were of similar composition, indicating minimal sediment disturbance during chamber installation. Of over 140 measurements conducted during the study period, only 4 chamber samples had dissolved oxygen levels less than $130 \mu \mathrm{mol} \mathrm{l}^{-1}$ and only 1 below $60 \mu \mathrm{mol} \mathrm{I}^{-1}$. While these data do not address changes within surficial sediments, they do indicate that enclosure of sediment and overlying water did not result in water column anoxia which has been shown to enhance sediment nutrient release.

Solute flux measurements occurring in similar sampling periods were pooled according to sediment type and chamber treatment (light vs dark) prior to statistical analysis. A Kruskal-Wallis analysis of variance by ranks test (Systat version 5.0, Systat, Inc. Evanston, IL. USA) was used to evaluate sampling period, and light and dark chamber differences in oxygen and nutrient flux measurements. A nonparametric multiple comparison test at an $\alpha$ level of 0.10 was used to determine where significant differences occurred (Zar 1984). A

Table 2. Sandy sediment (Stns EV 1 and EV 2) oxygen and nutrient flux measurements ( $\mu \mathrm{mol} \mathrm{m}^{-2} \mathrm{~h}^{-1}$ ). Negative values denote uptake by sediments. Standard error of the mean and sample size in parentheses. [Note: Summary statistics of $\mathrm{O}_{2}, \mathrm{NH}_{4}{ }^{+}$, and DIP sediment fluxes reported in Reay et al. (1992) are in error due to a miscalculation. Values reported here represent corrected values]

\begin{tabular}{|c|c|c|c|c|c|c|c|}
\hline Date & $\begin{array}{c}\text { Water } \\
\text { temp. }\left({ }^{\circ} \mathrm{C}\right)\end{array}$ & $\begin{array}{c}\text { Chamber } \\
\text { type }\end{array}$ & $\mathrm{O}_{2}$ & $\mathrm{NH}_{4}^{+}$ & $\mathrm{NO}_{3}^{-}$ & $\mathrm{NO}_{2}^{-}$ & DIP \\
\hline 7-8 May 1990 & $23.6-24.0$ & $\begin{array}{l}\text { Light } \\
\text { Dark }\end{array}$ & $\begin{array}{r}-806(174,6) \\
-2161(709,6)\end{array}$ & $\begin{array}{r}70(44,6) \\
103(32,6)\end{array}$ & $\begin{array}{l}-15(10,6) \\
-2(3,6)\end{array}$ & $\begin{array}{l}1(1,6) \\
1(1,6)\end{array}$ & $\begin{array}{r}1.9(0.7,6) \\
-0.3(0.8,6)\end{array}$ \\
\hline $17-18$ Jul 1990 & $29.0-30.0$ & $\begin{array}{l}\text { Light } \\
\text { Dark }\end{array}$ & $\begin{array}{r}-786(428,8) \\
-1704(703,6)\end{array}$ & $\begin{array}{r}50(11,8) \\
101(57,6)\end{array}$ & $\begin{array}{l}0(0,8) \\
1(1,6)\end{array}$ & $\begin{array}{r}0(0,8) \\
-1(0,6)\end{array}$ & $\begin{array}{l}1.1(0.4,8) \\
1.4(1.6,6)\end{array}$ \\
\hline $12-13$ Sep 1990 & $26.0-26.4$ & $\begin{array}{l}\text { Light } \\
\text { Dark }\end{array}$ & $\begin{array}{r}622(540,8) \\
-949(307,6)\end{array}$ & $\begin{array}{c}1(1,8) \\
62(45,7)\end{array}$ & $\begin{array}{l}7(3,8) \\
0(2,7)\end{array}$ & $\begin{array}{r}0(0,8) \\
-1(0,7)\end{array}$ & $\begin{array}{l}5.9(3.2,8) \\
9.6(5.3,7)\end{array}$ \\
\hline 19-20 Jan 1991 & $6.5-8.4$ & $\begin{array}{l}\text { Light } \\
\text { Dark }\end{array}$ & $\begin{array}{l}276(288,8) \\
188(353,6)\end{array}$ & $\begin{array}{r}0(11,8) \\
30(15,8)\end{array}$ & $\begin{array}{r}0(4,8) \\
12(4,8)\end{array}$ & $\begin{array}{l}-2(1,8) \\
-2(1,8)\end{array}$ & $\begin{array}{r}-1.1(0.8,8) \\
5.5(5.3,8)\end{array}$ \\
\hline 14-15 Apr 1991 & $14.5-14.7$ & $\begin{array}{l}\text { Light } \\
\text { Dark }\end{array}$ & $\begin{array}{r}2243(797,8) \\
-18(458,8)\end{array}$ & $\begin{array}{r}-13(7,8) \\
43(18,8)\end{array}$ & $\begin{array}{l}-21(10,8) \\
-23(8,8)\end{array}$ & $\begin{array}{l}0(1,8) \\
0(0,8)\end{array}$ & $\begin{array}{r}0.9(0.5,8) \\
-1.5(0.8,8)\end{array}$ \\
\hline
\end{tabular}


Table 3. Silt-clay sediment (Stns SC1 and SC2) oxygen and nutrient flux measurements ( $\mu \mathrm{mol} \mathrm{m}^{-2} \mathrm{~h}^{-1}$ ). Negative values denote uptake by sediments. Standard error of the mean and sample size in parentheses (see note in Table 2)

\begin{tabular}{|c|c|c|c|c|c|c|c|}
\hline Date & $\begin{array}{c}\text { Water } \\
\text { temp. }\left({ }^{\circ} \mathrm{C}\right)\end{array}$ & $\begin{array}{l}\text { Chamber } \\
\text { type }\end{array}$ & $\mathrm{O}_{2}$ & $\mathrm{NH}_{4}{ }^{*}$ & $\mathrm{NO}_{3}^{-}$ & $\mathrm{NO}_{2}^{-}$ & DIP \\
\hline 28-30 May 1990 & $19.0-22.0$ & $\begin{array}{l}\text { Light } \\
\text { Dark }\end{array}$ & $\begin{array}{l}-3643(363,6) \\
-2514(489,5)\end{array}$ & $\begin{array}{l}146(42,6) \\
184(51,5)\end{array}$ & $\begin{array}{l}3(2,6) \\
5(1,5)\end{array}$ & $\begin{array}{l}0(1,6) \\
0(0,5)\end{array}$ & $\begin{array}{r}8.6(2.0,6) \\
13.8(3.0,5)\end{array}$ \\
\hline $2-3$ Aug 1990 & $29.7-32.4$ & $\begin{array}{l}\text { Light } \\
\text { Dark }\end{array}$ & $\begin{array}{l}-4657(491,8) \\
-3844(424,8)\end{array}$ & $\begin{array}{l}184(44,8) \\
377(57,8)\end{array}$ & $\begin{array}{l}0(2,8) \\
4(3,8)\end{array}$ & $\begin{array}{l}0(0,8) \\
0(0,8)\end{array}$ & $\begin{array}{l}10.8(2.7,8) \\
20.7(4.3,8)\end{array}$ \\
\hline $11-12$ Oct 1990 & $24.7-26.0$ & $\begin{array}{l}\text { Light } \\
\text { Dark }\end{array}$ & $\begin{array}{l}-2247(479,8) \\
-1535(323,7)\end{array}$ & $\begin{array}{l}13(10,6) \\
-4(10,7)\end{array}$ & $\begin{array}{l}-3(1,6) \\
-2(1,7)\end{array}$ & $\begin{array}{l}0(0,6) \\
O(0,7)\end{array}$ & $\begin{array}{l}4.8(1.8,6) \\
1.4(1.4,7)\end{array}$ \\
\hline 10-11 Feb 1991 & $7.9-8.6$ & $\begin{array}{l}\text { Light } \\
\text { Dark }\end{array}$ & $\begin{array}{r}-710(244,8) \\
-1596(487,7)\end{array}$ & $\begin{array}{l}36(12,8) \\
76(37,8)\end{array}$ & $\begin{array}{r}-8(7,8) \\
-14(6,8)\end{array}$ & $\begin{array}{r}-1(0,8) \\
0(1,8)\end{array}$ & $\begin{array}{r}-0.1(0.7,8) \\
2.2(1.1,8)\end{array}$ \\
\hline 29-30 Apr 1991 & $23.8-24.2$ & $\begin{array}{l}\text { Light } \\
\text { Dark }\end{array}$ & $\begin{array}{r}507(288,8) \\
-1559(119,8)\end{array}$ & $\begin{array}{r}86(34,8) \\
150(19,8)\end{array}$ & $\begin{array}{l}-20(5,8) \\
-12(4,8)\end{array}$ & $\begin{array}{l}-4(1,8) \\
-4(1,8)\end{array}$ & $\begin{array}{l}0.4(0.8,8) \\
3.4(0.9,8)\end{array}$ \\
\hline
\end{tabular}

Spearman rank correlation $\left(r_{s}\right)$ at an $\alpha$ level of 0.05 was used to assess the association between external factors that may regulate or influence sediment solute fluxes.

Mean sandy sediment oxygen flux in light chambers was $369 \mu \mathrm{mol} \mathrm{m} \mathrm{m}^{-2} \mathrm{~h}^{-1}$ (range: -2454 to 6647 ) and $-872 \mu \mathrm{mol} \mathrm{m}^{-2} \mathrm{~h}^{-1}$ (range: -4601 to 1839 ) in dark chambers over the study period. Mean silt-clay sediment oxygen flux in light chambers was $-2062 \mu \mathrm{mol}$ $\mathrm{m}^{-2} \mathrm{~h}^{-1}$ (range: -6859 to 1989 ) and $-2220 \mu \mathrm{mol} \mathrm{m} \mathrm{m}^{-2} \mathrm{~h}^{-1}$ in dark chambers (range: -5323 to 7 ). While mean midday light chamber oxygen fluxes to sandy sediment were reduced as compared to dark chamber treatments, or showed oxygen production for all sampling periods, significant differences between chamber treatments occurred only between the fall (September 1990) and early spring (April 1991) sampling periods. In comparison, silt-clay sediment oxygen fluxes in light chambers were reduced as compared to dark chambers, or showed oxygen production in only 2 of the 5 sampling periods; significant differences only occurred during the early spring sampling period.

Significant differences occurred in light chamber oxygen fluxes between sampling periods for both sandy $(\mathrm{p}=$ $<0.01)$ and silt-clay $(\mathrm{p}<0.01)$ sediments. Early spring sandy and silt-clay sediment oxygen production was significantly greater than that measured in late spring (May 1990) and summer (July and August 1990) which was characterized by sediment uptake of oxygen. Temporal differences in benthic community respiration were also observed for both sediment types (sand: $p=0.06$; silt-clay: $\mathrm{p}=<0.01$ ) with elevated rates being associated with late spring and summer sampling periods. Significant inverse relationships were found between sediment oxygen fluxes and temperature for light (sand: $\mathrm{r}_{\mathrm{S}}=$

Table 4. Seasonal and annual estimates of sediment ammonium, nitrate, nitrite, DIN and DIP fluxes (mmol $\mathrm{m}^{-2}$ ). Negative values denote uptake by sediments. Seasonal nutrient flux was determined by multiplying daily flux by the number of days in the season. Daily nutrient flux $=($ mean hourly transparent dome rate $\times$ photoperiod $)+($ mean dark dome rate $\times$ night period $)$. Daily photoperiods were determined from sunrise/sunset data (The World Almanac 1990/1991) following corrections for latitude and standard time meridian

\begin{tabular}{|c|c|c|c|c|c|c|}
\hline Season & $\begin{array}{l}\text { Sediment } \\
\text { type }\end{array}$ & $\mathrm{NH}_{4}^{+}$ & $\mathrm{NO}_{3}^{-}$ & $\mathrm{NO}_{2}^{-}$ & DIN & DIP \\
\hline Spring (Mar-May) & $\begin{array}{l}\text { Sand } \\
\text { Silt-clay }\end{array}$ & $\begin{array}{r}96.2 \\
298.2\end{array}$ & $\begin{array}{l}-36.2 \\
-17.7\end{array}$ & $\begin{array}{r}0.9 \\
-5.2\end{array}$ & $\begin{array}{r}60.9 \\
275.3\end{array}$ & $\begin{array}{r}0.6 \\
12.1\end{array}$ \\
\hline Summer (Jun-Aug) & $\begin{array}{l}\text { Sand } \\
\text { Silt-clay }\end{array}$ & $\begin{array}{l}156.3 \\
579.9\end{array}$ & $\begin{array}{l}0.9 \\
3.6\end{array}$ & $\begin{array}{l}-0.9 \\
<0.1\end{array}$ & $\begin{array}{l}156.3 \\
583.5\end{array}$ & $\begin{array}{r}2.7 \\
32.8\end{array}$ \\
\hline Fall (Sep-Nov) & $\begin{array}{l}\text { Sand } \\
\text { Silt-clay }\end{array}$ & $\begin{array}{r}72.8 \\
8.7\end{array}$ & $\begin{array}{r}7.2 \\
-4.6\end{array}$ & $\begin{array}{l}-1.2 \\
<0.1\end{array}$ & $\begin{array}{r}78.8 \\
4.1\end{array}$ & $\begin{array}{r}17.2 \\
6.5\end{array}$ \\
\hline Winter (Dec-Feb) & $\begin{array}{l}\text { Sand } \\
\text { Silt-clay }\end{array}$ & $\begin{array}{r}37.5 \\
127.8\end{array}$ & $\begin{array}{r}15.0 \\
-24.8\end{array}$ & $\begin{array}{l}-4.3 \\
-0.9\end{array}$ & $\begin{array}{r}48.2 \\
102.1\end{array}$ & $\begin{array}{l}5.9 \\
1.8\end{array}$ \\
\hline Annual & $\begin{array}{l}\text { Sand } \\
\text { Silt-clay }\end{array}$ & $\begin{array}{r}362.8 \\
1014.6\end{array}$ & $\begin{array}{l}-13.1 \\
-43.5\end{array}$ & $\begin{array}{l}-5.5 \\
-6.1\end{array}$ & $\begin{array}{l}344.2 \\
965.0\end{array}$ & $\begin{array}{l}26.4 \\
53.2\end{array}$ \\
\hline
\end{tabular}


$-0.41, \mathrm{~N}=38$; silt-clay: $\mathrm{r}_{\mathrm{S}}=-0.42, \mathrm{~N}=36$ ) and dark (sand: $\mathrm{r}_{\mathrm{S}}=-0.51, \mathrm{~N}=32$; silt-clay: $\mathrm{r}_{\mathrm{S}}=-0.41, \mathrm{~N}=35$ ) chambers. Light chamber oxygen fluxes for silt-clay were significantly lower than for sandy sediments during all comparable seasonal measurements, whereas silt-clay sediment community respiration was greater than that in sandy sediments during the summer and early spring sampling periods.

Based on individual measurements, ammonium accounted for $79 \%$ of the inorganic nitrogen flux to the water column from sandy sediments and $94 \%$ for siltclay sediments. Sandy sediment ammonium fluxes ranged from -44 to 250 and -29 to $358 \mu \mathrm{mol} \mathrm{m}^{-2} \mathrm{~h}^{-1}$ in light and dark chambers, respectively. Ammonium fluxes ranged from -30 to $335 \mu \mathrm{mol} \mathrm{m} \mathrm{m}^{-2} \mathrm{~h}^{-1}$ in light chambers and -21 to $615 \mu \mathrm{mol} \mathrm{m}{ }^{-2} \mathrm{~h}^{-1}$ in dark chambers for the silt-clay sediment. Mean dark chamber sandy sediment ammonium fluxes were greater than light chamber measurements for all sampling periods; significant differences occurred during the winter and early spring. Except for the fall sampling period, siltclay sediments displayed a similar pattern of elevated ammonium fluxes being associated with dark chamber treatments; differences were significant for the summer sampling period. Incorporating data over all sampling periods, ammonium fluxes were reduced approximately 40 and $70 \%$ in light chambers as compared to dark chamber treatments for silt-clay and sandy sediments, respectively. Elevated fluxes of ammonium were associated with the late spring and summer sampling periods for both sediment types and chamber treatments. Significant differences occurred in light chamber treatments for sand (summer > winter, early spring) and silt-clay (late spring, summer $>$ fall) sediments, and in the silt-clay dark chamber treatment (late spring $>$ fall $_{i}$ summer $>$ fall, winter).

Sediment-water column nitrate exchanges were generally low and variable in direction. Nitrate fluxes ranged from -71 to $28 \mu \mathrm{mol} \mathrm{m} \mathrm{m}^{-2} \mathrm{~h}^{-1}$ for sandy sediments andfrom -42 to $25 \mu \mathrm{mol} \mathrm{m} \mathrm{m}^{-2} \mathrm{~h}^{-1}$ for silt-clay sediments. Elevated uptake of nitrate by the sediment was associated with winter and spring seasons. Incorporating light and dark chamber data, sediment nitrate uptake was significantly correlated to water column nitrate concentrations for both silt-clay $\left(\Gamma_{S}=0.72, N=\right.$ $48)$ and sandy $\left(r_{S}=0.83, N=36\right)$ sediments. Sediment nitrite fluxes represented a minor component of sediment inorganic nitrogen exchanges with the overlying water column; individual values ranged between -8 and $3 \mu \mathrm{mol} \mathrm{m} \mathrm{m}^{-2} \mathrm{~h}^{-1}$.

Benthic exchange rates of DIP for sandy sediments varied from -5.3 to $15.9 \mu \mathrm{mol} \mathrm{m}^{-2} \mathrm{~h}^{-1}$ in light chambers and -5.3 to $42.0 \mu \mathrm{mol} \mathrm{m}^{-2} \mathrm{~h}^{-1}$ in dark flux chambers. Sediment DIP flux rates ranged from -3.3 to 19.9 and -1.8 to $35.7 \mu \mathrm{mol} \mathrm{m}^{-2} \mathrm{~h}^{-1}$ for light and dark chambers, re- spectively, for silt-clay sediments. Significant differences in DIP flux rates occurred between sampling periods for light $(p=<0.01)$ and dark $(p<0.01)$ chamber treatments at the silt-clay sediment sites, whereas no significant differences were found for sandy sediments. Following a temporal pattern similar to that of ammonium, elevated fluxes of DIP from silt-clay sediments were associated with the late spring and summer sampling periods. Significant differences occurred in both light chamber (late spring > winter; summer > winter, early spring) and dark chamber (late spring $>$ fall; summer $>$ fall, winter, early spring) treatments. While elevated in 4 of the 5 sampling periods, dark chamber siltclay sediment DIP fluxes were only significantly $(p=$ 0.02 ) greater than light chamber measurements during the early spring sampling period which coincided with the only sampling period that exhibited a positive mean NCP. Dark chamber DIP flux rates were never significantly greater than light chamber rates for the sandy sediments. Pooling data over sampling periods, sand and silt-clay flux rates of DIP were reduced approximately $40 \%$ in light chambers as compared to dark chamber treatments. Silt-clay light chamber DIP fluxes were significantly greater than those of sandy sediments during the late spring and summer sampling periods, whereas silt-clay dark chamber fluxes were greater than those of sandy sediments during both spring sampling periods in addition to the summer.

Sediment ammonium fluxes showed a significant positive relationship to benthic aerobic respiration for sandy $\left(r^{2}=0.25, p=<0.01\right)$ and silt-clay $\left(r^{2}=0.53, p=\right.$ $<0.01$ ) (Fig. 2) sediments. A significant positive relationship was found between sediment DIP flux and benthic aerobic respiration for the silt-clay sediments $\left(\mathrm{r}^{2}=\right.$ $0.72, p=<0.01)$ but not for sandy sediments $\left(r^{2}=<0.01, p\right.$ $=0.70$ ) (Fig. 3). Benthic ammonium and DIP fluxes showed a significant positive linear relationship $\left(\mathrm{r}^{2}=\right.$ $0.63, p=<0.01$ ) with a slope of 11.9 units for the high organic matter, silt-clay sediments (Fig. 4). No such relátionship was observed for ammonium and DIP sediment fluxes for the sandy sediments $\left(r^{2}=0.14, p=0.13\right)$ (Fig. 4). Ammonium and DIP relationships were determined on paired data from dark chambers that exhibited positive sediment ammonium and DIP fluxes.

\section{Water column productivity and photosynthetic pigments}

Water column gross primary productivity displayed a unimodal pattern with elevated rates associated with midsummer sampling periods (Fig. 5). Peak water column gross productivity $\left(5.1 \mathrm{~g} \mathrm{C} \mathrm{m}^{-2} \mathrm{~d}^{-1}\right)$ occurred during summer and coincided with maximum total chl $a$ levels of $62 \mathrm{\mu g} \mathrm{l}^{-1}$. Gross water column productivity de- 
A
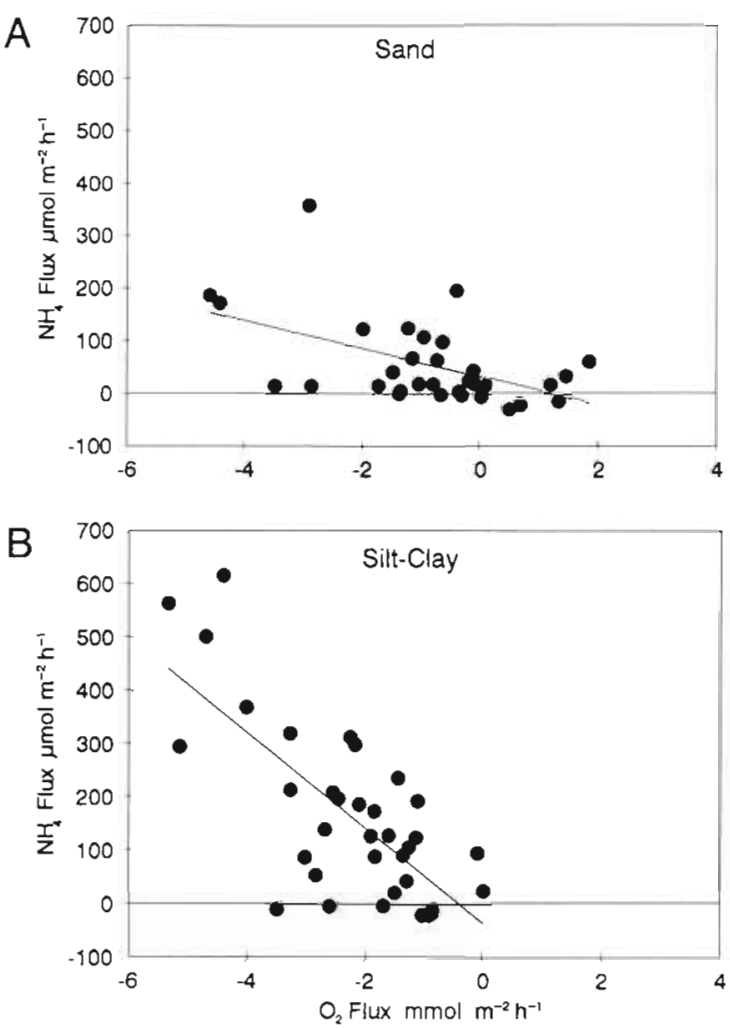

Fig. 2. Sediment ammonium fluxes versus aerobic respiration for (A) sand $\left(r^{2}=0.25, p=<0.01\right)$ and (B) silt-clay $\left(r^{2}=0.53\right.$ $\mathrm{p}=<0.01)$ sediments

clined steadily from fall $\left(-1.3 \mathrm{~g} \mathrm{C} \mathrm{m}^{-2} \mathrm{~d}^{-1}\right)$ through winter $\left(\sim 0.2 \mathrm{~g} \mathrm{C} \mathrm{m}^{-2} \mathrm{~d}^{-1}\right)$ sampling periods. Water column total chl a concentrations remained relatively stable $\left(\sim 10 \mu \mathrm{g}^{-1}\right)$ from late fall through early spring sampling periods.

Mean total chl $a$, functional chl $a$, and phaeopigment concentrations for sandy and silt-clay sediments by sampling period are presented in Fig. 6. Monthly mean total chl a concentrations ranged from 64.5 to $133.1 \mathrm{mg} \mathrm{m}^{-2}$ for silt-clay sediments and 134.8 to $222.5 \mathrm{mg} \mathrm{m}^{-2}$ for sandy sediments. Sandy sediment total and functional chl a levels were significantly greater than siltclay sediment levels for all seasons. On average, functional chl a represented $40 \%$ of the total chl $a$ for the silt-clay and $80 \%$ for sandy sediments.

\section{DISCUSSION}

Based on dry bulk densities and grain size mass ratios, the sand and silt-clay sediments of this study exemplified the domi-
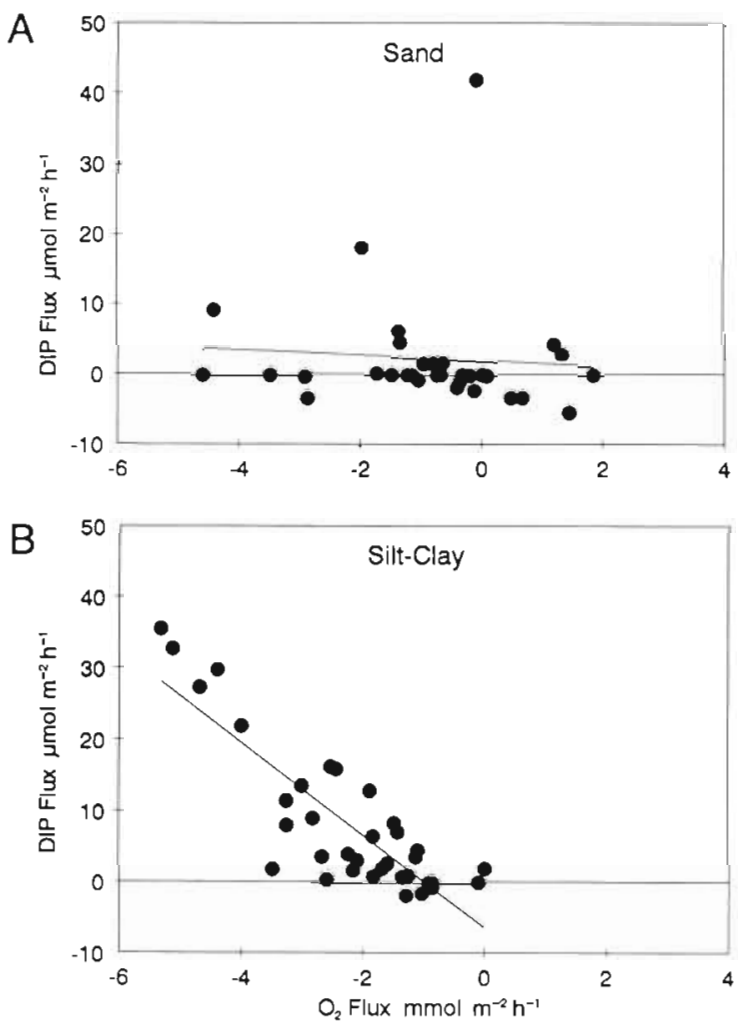

Fig. 3. Sediment DIP fluxes versus aerobic respiration for (A) sand $\left(\mathrm{r}^{2}=<0.01, \mathrm{p}=0.70\right)$ and $(\mathrm{B})$ silt-clay $\left(\mathrm{r}^{2}=0.72, \mathrm{p}=\right.$ $<0.01$ ) sediments

nant sediment types found within the Chesapeake Bay system (Hill \& Halka 1988). The nearshore sites were representative of relatively high and low wave-energy environments which were characterized by inorganic

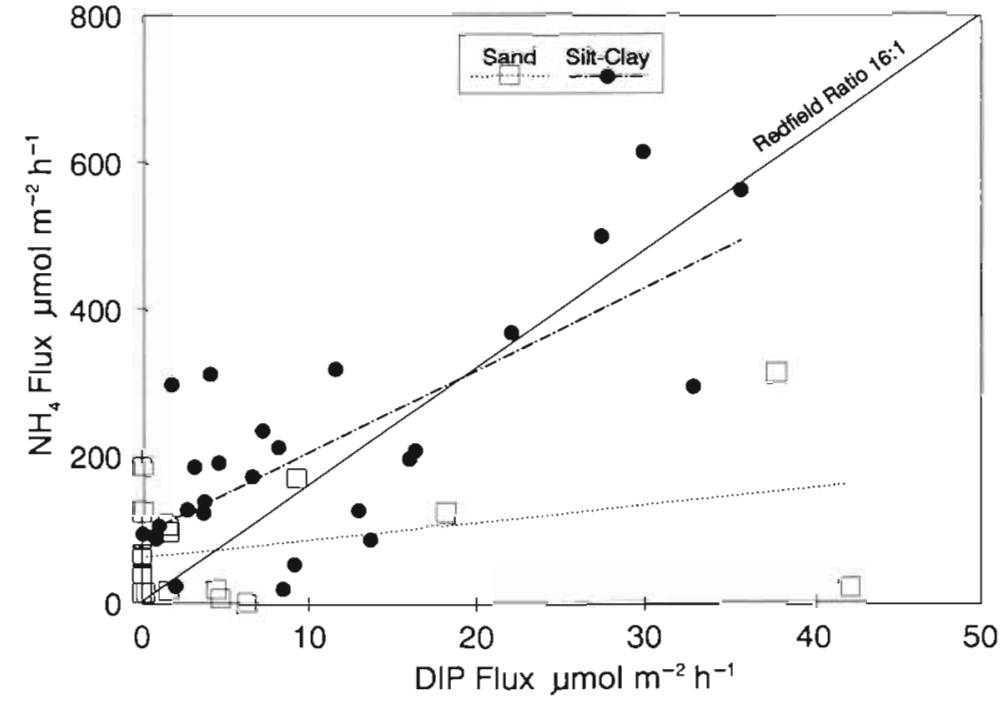

Fig. 4. Sediment ammonium versus DIP fluxes for sandy $\left(r^{2}=0.14, p=0.13\right)$ and silt-clay $\left(\mathrm{r}^{2}=0.63, \mathrm{p}=<0.01\right)$ sediments 


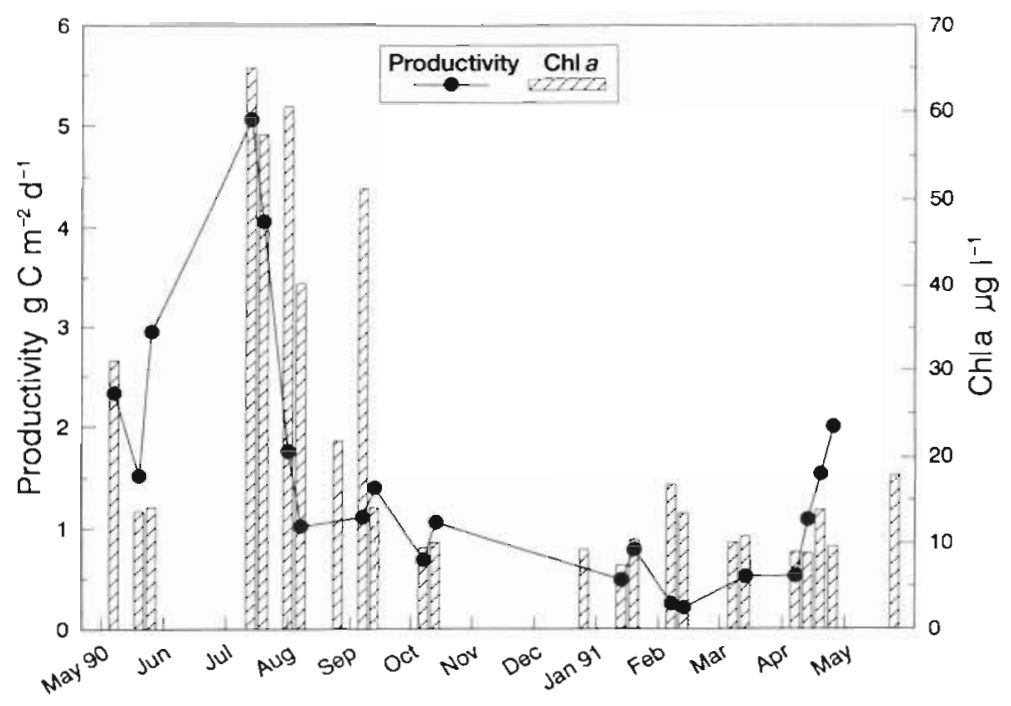

Fig. 5. Monthly variations in water column gross primary productivity and total chlorophyll a levels within Cherrystone Inlet during the sampling period May 1990 to May 1991

sandy and organic silt-clay sediments, respectively. During the study period, the photic zone varied from a minimum of $0.7 \mathrm{~m}$ in summer to $6.1 \mathrm{~m}$ during winter. Integration of water depths showed that the entire bot-
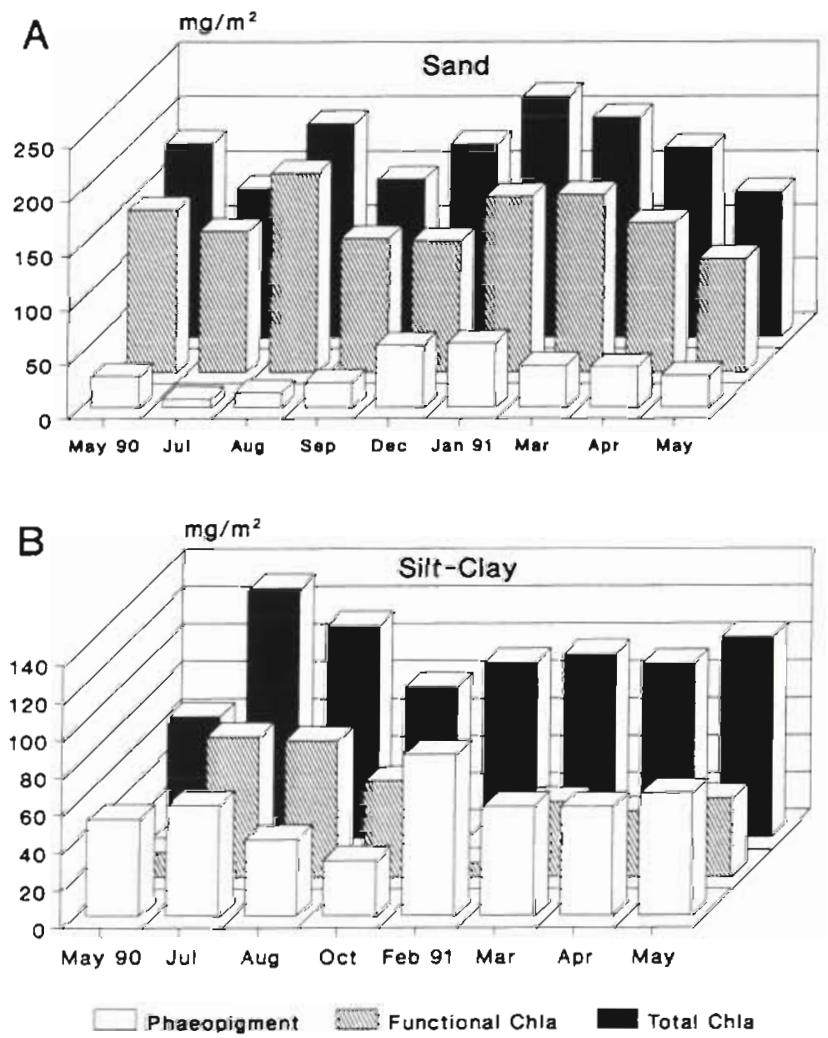

Fig. 6. Benthic photosynthetıc pigment concentrations for (A) sand and (B) silt-clay sediments tom surface of the inlet received sufficient light energy to support benthic microalgal communities during winter and early spring, as compared to the summer when approximately $50 \%$ of the bottom area received adequate light energy (Fig. 1). Considerable amounts of functional chl a were found in nearshore sediments throughout the year, however there was an uneven distribution based on sediment type. Microalgal standing stock was greater year-round in surficial sandy sediments as compared to silt-clay sediments. Moreover, functional chl a comprised a large fraction ( $\sim 80 \%$ ) of total chl a levels for sandy sediments, whereas degraded phaeopigment components dominated $(\sim 60 \%)$ total chl a concentrations for siltclay sediments. Increased percentages of phaeopigment to total chl a indicated appreciable amounts of photosynthetic pigment degradation was occurring at the sediment-water interface in the depositional environments dominated by silt-clay sediments.

Benthic aerobic respiration and NCP demonstrated a temperate seasonal pattern with values comparable to similar estuarine and marine sediments (Boynton et al. 1980, Propp et al. 1980, Phoel et al. 1981, Hopkinson \& Wetzel 1982, Rizzo 1986, Teague et al. 1988). Highest rates of respiration occurred during the late spring and summer sampling periods. Although detectable throughout the study period, sandy sediment photosynthetic activity at midday exceeded benthic respiration only during fall through early spring sampling periods. Elevated sandy sediment NCP coincided with heightened benthic total chl a pigment levels, increased light penetration, and periods of reduced benthic aerobic respiration. Silt-clay sediment photosynthetic activity was detected during the winter and early spring sampling periods and only exceeded benthic aerobic respiration rates during the early spring sampling period. In contrast to sandy sediments, periods of elevated NCP were not associated with elevated benthic total chl a pigment levels for silt-clay sediments. Boynton et al. (1981) reported that chemical oxygen demand, caused by the oxidation of reduced compounds originating from anaerobic metabolism, can represent a greater percentage of the sediment oxygen demand in silt-clay sediments $(35 \%)$ as compared to sandy sediments $(10 \%)$. This may partially explain the lack of oxygen production observed in light chambers deployed at the silt-clay sediment sites. Based on metabolic rate estimates and benthic chl a levels, nearshore sandy sediments were more productive than silt-clay sediments. This result concurred 

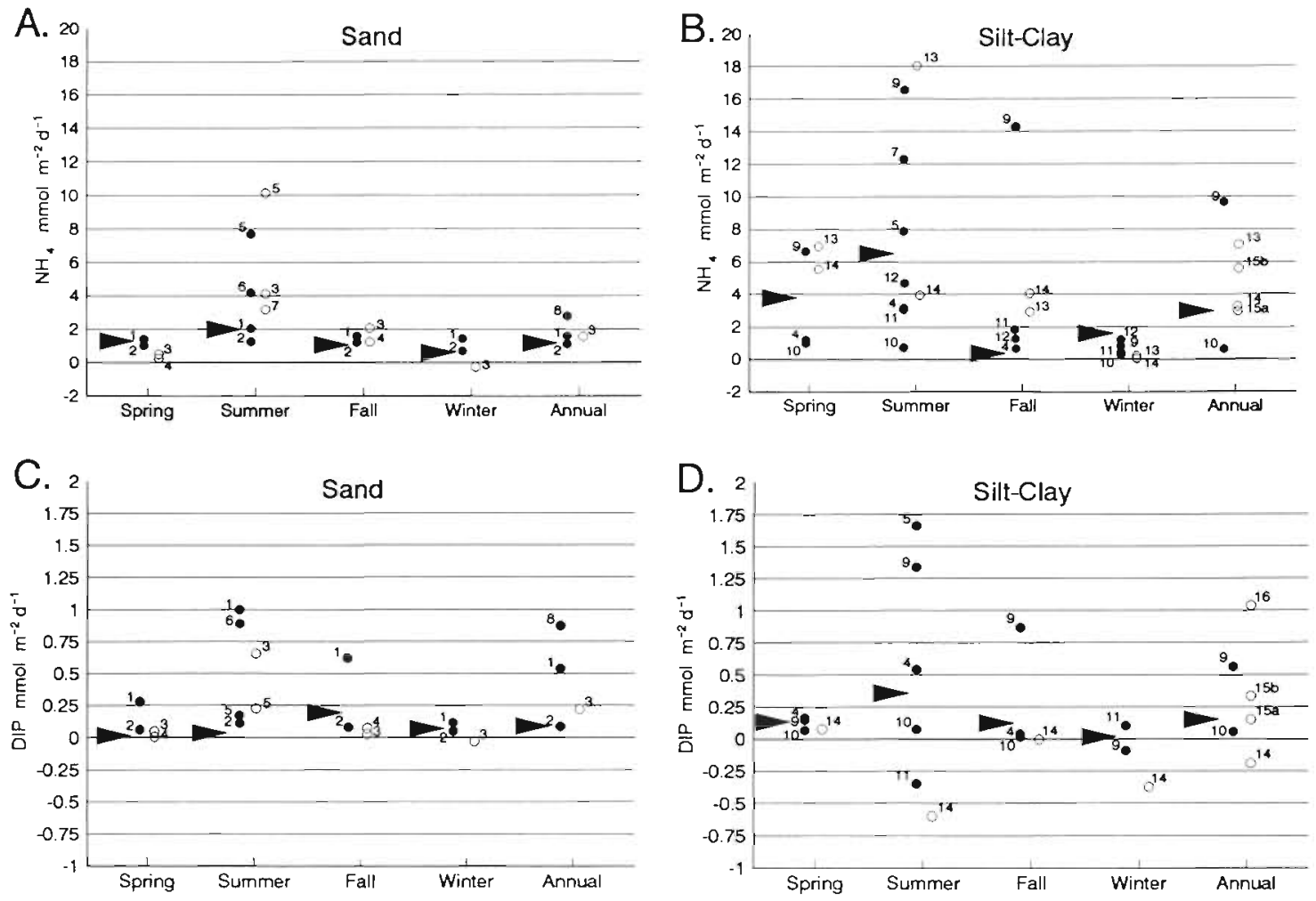

Fig. 7. Estuarine and coastal sediment (A, B) ammonium and (C, D) DIP fluxes (seasonal and annual mean) from selected studies utilizing benthic chamber methodology. (o) Shallow water environments (water depth $\leq 3 \mathrm{~m}$ ); ( $\bullet$ ) deeper (water depth $>3 \mathrm{~m}$ ) water environments. ( Values reported in this study. References are as follows:

1. Hopkinson (1987). Georgia Bight, GA. 6. Hopkinson \& Wetzel (1982). Georgia Depth $<10 \mathrm{~m}$; Chamber: opaque

2. Hartwig (1976). La Jolla Bight, CA. Depth $18.3 \mathrm{~m}$; Chamber: transparent and opaque.

3. Rizzo (1990). York River estuary, VA Depth $<2 \mathrm{~m}$; Chamber: transparent and opaque. (Seasonal fluxes estimated from available data.)

4. Propp et al. (1980). Sea of Japan, Vostok Bay. Depth 3, $7 \mathrm{~m}$; Chamber: transparent and opaque.

5. Callender \& Hammond (1982). Potomac River estuary, MD. Depth 3, 5 to $9 \mathrm{~m}$; Chamber: opaque.
Bight, GA. Depth $<10 \mathrm{~m}$; Chamber. opaque.

7. Phoel et al. (1981). York River estuary, VA. Depth 3, $16 \mathrm{~m}$; Chamber: transparent.

8. Rowe et al. (1977). Cap Blanc, Spanish Sahara. Depth $25 \mathrm{~m}$ (Stn 162); Chamber: not known.

9. Klump \& Martens (1981). Cape Lookout Bight, NC. Depth $8.5 \mathrm{~m}$; Chamber: not known

10. Balzer et al. (1983), Balzer (1984). Kiel Bight, Western Baltic. Depth $20 \mathrm{~m}$; Chamber: transparent.
11. Rowe et al. (1975). Buzzards Bay, MA Depth $17 \mathrm{~m}$; Chamber: opaque

12. Flint \& Kamykowski (1984). Gulf of Mexico, TX. Depth $14 \mathrm{~m}$; Chamber: opaque.

13. Kemp \& Boynton (1984). Patuxent River estuary, MD. Depth $3 \mathrm{~m}$; Chamber: opaque.

14. Teague et al. (1988). Fourleague Bay, LA. Depth $1.5 \mathrm{~m}$; Chamber: opaque.

15. Fisher et al. (1982). (a) South and (b) Neuse River estuary, NC. Depth 2, $3 \mathrm{~m}$; Chamber: transparent.

16. Boynton et al. (1980). Patuxent River estuary, MD. Depth $3 \mathrm{~m}_{\text {; }}$ Chamber: opaque. with those of others investigating benthic primary productivity differences between coarse and fine-grained sediments in estuarine and marine ecosystems (Riznyk \& Phinney 1972, Propp et al. 1980).

Ammonium was the dominant form of inorganic nitrogen released from sandy sediments, with elevated fluxes occurring in late spring and summer. Individual ammonium flux rates ranged from -44 to $358 \mu \mathrm{mol} \mathrm{m} \mathrm{m}^{-2}$ $\mathrm{h}^{-1}$ with an estimated annual release of $363 \mathrm{mmol} \mathrm{m}^{-2}$.
While sandy sediment ammonium fluxes were correlated to benthic aerobic respiration rates, the relationship was marginal and not as strong as that observed for silt-clay sediments. A seasonal and annual comprehensive summary of reported ammonium and DIP fluxes for estuarine and marine sediments, utilizing similar methodology, is presented in Fig. 7. In situ ammonium fluxes and temporal trend were similar to those reported for sandy shoal and deeper offshore 
sandy sediments (Fig 7A). Incorporating this study, the mean annual flux of ammonium from sandy sediments was $529 \mathrm{mmol} \mathrm{m}^{-2}$ (range: 318 to 964 ).

Averaging less than $-5 \mu \mathrm{mol} \mathrm{m} \mathrm{m}^{-2} \mathrm{~h}^{-1}$, nitrate fluxes were correlated to water column nitrate concentrations with maximum sediment uptake rates occurring during spring sampling periods. While the nearshore sandy sediments represented an overall sink for nitrate, sediments located immediately adjacent to the shoreline in Cherrystone Inlet have been shown to be influenced by groundwater discharge and represent a significant source of nitrate to the water column (Reay et al. 1992b, Simmons et al. 1992); maximum reported nitrate fluxes were on the order of $2000 \mu \mathrm{mol} \mathrm{m} \mathrm{m}^{-2} \mathrm{~h}^{-1}$. Sandy sediment DIP fluxes were generally low and frequently towards the sediment. No significant relationship was found between sandy sediment DIP fluxes and benthic aerobic respiration. In contrast with several studies, temporal variations in DIP fluxes were not characteristic of a temperate seasonal pattern (Fig. 7C). Sandy sediments were estimated to release 26.4 $\mathrm{mmol} \mathrm{m} \mathrm{m}^{-2}$ of DIP annually; the annual flux based on all studies was $129.9 \mathrm{mmol} \mathrm{m}^{-2}$ (range: 26.4 to 315.4 ).

As with sandy sediments, ammonium was the dominant form of inorganic nitrogen released from silt-clay sediments, with elevated fluxes occurring in late spring and summer. Benthic ammonium fluxes were dependent on benthic aerobic respiration rates which accounted for $53 \%$ of the observed variations. In situ ammonium flux rates, with an overall mean of 127 $\mu \mathrm{mol} \mathrm{m} \mathrm{m}^{-2} \mathrm{~h}^{-1}$ and values ranging from -30 to $615 \mu \mathrm{mol}$ $\mathrm{m}^{-2} \mathrm{~h}^{-1}$, are similar to reported values for finer sediments in estuarine and marine environments (Fig. 7B). Annually, ammonium release from silt-clay sediments was approximately 2 -fold greater than from sandy sediments. Incorporating this study, the mean annual ammonium flux from fine-grained estuarine and marine sediments was $1593 \mathrm{mmol} \mathrm{m}{ }^{-2}$ (range: 161 to 3408). Nitrate uptake by silt-clay sediments was correlated to water column nitrate concentrations. Elevated nitrate uptake rates, on the order of $20 \mu \mathrm{mol} \mathrm{m} \mathrm{m}^{-2}$ $\mathrm{h}^{-1}$, occurred during the winter and early spring when water column nitrate levels are at a maximum due to elevated freshwater input from creek baseflow and direct groundwater discharge (Reay et al. 1992b) During the late spring and summer, nitrate fluxes were minimal and variable in direction. This seasonal pattern of sediment-water column nitrate exchange was similar to that reported by Boynton et al. (1981) for the Patuxent River estuary, a tributary of the upper Chesapeake Bay. Nitrate fluxes directed towards the sediments were comparable in magnitude to denitrification rates reported for sediments dominated by silts and clays (Jenkins \& Kemp 1984, Twilley \& Kemp 1987).
Silt-clay sediment DIP flux rates varied from -3.3 to $35.7 \mu \mathrm{mol} \mathrm{m}{ }^{-2} \mathrm{~h}^{-1}$, and for the most part, fluxes were from the sediment to the water column. This range was consistent with values reported for estuarine and marine fine-textured sediments. In contrast to sandy sediments, silt-clay DIP fluxes were strongly correlated to benthic aerobic respiration rates, which explained $72 \%$ of the observed variations. In addition, silt-clay DIP fluxes exhibited a distinct seasonal pattern, as described for ammonium (Fig. 7D). On an annual basis, silt-clay sediments were estimated to release $53.2 \mathrm{mmol} \mathrm{m} \mathrm{m}^{-2}$, while the mean for reported studies was $109.1 \mathrm{mmol} \mathrm{m}^{-2}$ (range: -70.1 to 376.7 ). The ratio of silt-clay sediment ammonium to DIP fluxes $(12: 1)$ was in relative agreement to a 16:1 DIN:DIP ratio expected from aerobic mineralization of marine phytoplankton (Redfield et al. 1963). These results indicate a strong linkage between autotrophic communities producing organic material and silt-clay aerobic heterotrophic communities degrading the deposited or benthic derived organic matter at the sediment-water interface.

Biological uptake of nutrients by benthic microalgal communities significantly altered ammonium and DIP fluxes across the sediment-water interface. Sandy sediment DIP and ammonium flux rates were reduced approximately 40 and $70 \%$, respectively, in light chambers as compared to dark chambers. Flux rates of ammonium and DIP were reduced $40 \%$ in light chambers as compared to dark chambers for silt-clay sediments. Reduced ammonium and DIP benthic fluxes or sediment uptake of ammonium and DIP coincided with periods of enhanced benthic NCP. Propp et al. (1980) and Rizzo (1990) reported similar results regarding nitrogen uptake by benthic microalgal communities in sandy substrates. In addition to reduced flux rates, the direction of ammonium and DIP fluxes indicated sediment uptake during periods of elevated NCP for sandy sediments. Nutrient fluxes predicted from concentration gradients across the sediment-water interface would suggest a unidirectional flux from the sandy sediments to the overlying water column (Reay et al. 1992a).

A critical water quality issue is the seasonal response of phytoplankton growth to nutrient availability. Maximum levels of phytoplankton production and biomass occurred during the summer months in Cherrystone Inlet. This pattern was consistent with other Chesapeake Bay environments (Kemp \& Boynton 1984). The importance of sediment nutrient fluxes can be examined in terms of phytoplankton nutrient requirements. Seasonal water column gross productivity, phytoplankton nutrient demand, and percentage nutrient supplied by sediments are listed in Table 5 . On an annual basis, nutrient flux from the silt-clay sediments was estimated to supply $11 \%$ of the inorganic phos- 
phorus and $14 \%$ of the inorganic nitrogen required for water column gross primary productivity. Sandy sediment inorganic phosphorus and ammonium fluxes were estimated to supply 11 and $6 \%$, respectively, of the annual planktonic nutrient assimilation demand. Fisher et al. (1982) reported that sediments could annually supply an average of $28 \%$ (range: 0 to 75 ) of the phosphorus and $35 \%$ (range: 0 to 79 ) of the nitrogen required for primary productivity in relatively shallow marine environments. More specifically pertaining to the Chesapeake Bay system, Boynton et al. (1980) estimated that benthic fluxes of ammonium and phosphate could fulfill 0 to $190 \%$ of the daily nitrogen and 52 to $330 \%$ of the daily phosphorus requirements of phytoplankton in the Patuxent River estuary. Benthic nutrient fluxes were estimated to satisfy $35 \%$ of the gross primary productivity nitrogen demands in the upper Potomac River estuary and $27 \%$ of the phosphorus demand (Callender \& Hammond 1982). Rizzo (1990) reported that sandy shoal sediments in the York River supplied 36 and $75 \%$ of phytoplankton nitrogen and phosphorus requirements, respectively. Using mean annual ammonium flux rates from Fig, $7 \mathrm{~A}, \mathrm{~B}$ and Redfield C:N:P ratios, sandy and silt-clay sediments could be expected to support approximately 40 and $130 \mathrm{~g} \mathrm{C}$, respectively, of water column primary productivity on a square-meter basis. In terms of phytoplankton phosphorus requirements, sandy and silt-clay sediments could support approximately $150 \mathrm{~g} C$ of primary productivity.

In order for sediment-derived nutrients to be of ecological significance, nutrient exchange must coincide with periods of elevated phytoplankton productivity. Positive correlations between sandy and silt-clay sedi- ment DIN fluxes and phytoplankton DIN assimilatory demands based on Redfield ratios emphasize the importance and interdependence of sediment heterotrophic and water column autotrophic processes (Fig. 8). While silt-clay sediments show a similar trend, the phosphorus water column demand and sediment flux relationship was not significant. Similar findings that demonstrate increased benthic nutrient fluxes with increasing water column primary productivity in shallow marine and estuarine environments have been reported by Fisher et al. (1982) and Kemp et al. (1982).

The relative importance of sediment nutrient fluxes versus water column nutrient stock to water column productivity demand was a function of both sediment type and season. During summer, when water column nutrient demand was greatest and water column nutrient concentrations low, DIN and DIP contributions to water column demand from silt-clay sediments were greater than those from water column DIN and DIP stocks, which could support approximately $7 \%$ of the phytoplankton demand. In contrast, sandy sediment DIN and DIP contributions to phytoplankton demand were smaller than those observed for the water column stocks. In winter, when water column nutrient demand was low and water column DIN levels are high, water column DIN stock was sufficient to supply over $100 \%$ of the water column DIN demand. DIN fluxes from sandy and silt-clay sediments could only supply 8 and $16 \%$, respectively, of the water column DIN requirements during winter. As with DIN, water column DIP stocks $(49 \%)$ could supply a greater percentage of the winter water column DIP assimilation requirements than both sandy and silt-clay sediment DIP fluxes. The

Table 5. Relative importance of benthic fluxes of DIN and DIP to water column nutrient assimilation demands. Water column nitrogen and phosphorus demand computed from C:N:P Redfield ratios (106:16:1) (Redfield et al. 1963) and seasonally integrated gross productivity estimates. Seasonal gross productivity estimates were calculated from areas under the productivity curve in Fig. 5

\begin{tabular}{|c|c|c|c|c|c|c|}
\hline Season & $\begin{array}{l}\text { Gross } \\
\text { productivity } \\
\left(\mathrm{gC} \mathrm{m}^{-2}\right)\end{array}$ & $\begin{array}{c}\text { DIN } \\
\text { demand } \\
\left(\mathrm{mmol} \mathrm{m}^{-2}\right)\end{array}$ & $\begin{array}{c}\text { DIP } \\
\text { demand } \\
\left(\mathrm{mmol} \mathrm{m}^{-2}\right)\end{array}$ & $\begin{array}{l}\text { Sediment } \\
\text { type }\end{array}$ & $\begin{array}{l}\% \text { Nutrients } \\
\text { supplied by } \\
\text { sediment } \\
\text { DIN flux }\end{array}$ & $\begin{array}{l}\% \text { Nutrients } \\
\text { supplied by } \\
\text { sediment } \\
\text { DIP flux }\end{array}$ \\
\hline Spring (Mar-May) & 107.36 & 1349.9 & 84.4 & $\begin{array}{l}\text { Sand } \\
\text { Silt-clay }\end{array}$ & $\begin{array}{r}5 \\
20\end{array}$ & $\begin{array}{r}1 \\
14\end{array}$ \\
\hline Summer (Jun-Aug) & 270.94 & 3405.7 & 213.0 & $\begin{array}{l}\text { Sand } \\
\text { Silt-clay }\end{array}$ & $\begin{array}{r}5 \\
17\end{array}$ & $\begin{array}{r}1 \\
15\end{array}$ \\
\hline Fall (Sep-Nov) & 89.04 & 1119.2 & 70.0 & $\begin{array}{l}\text { Sand } \\
\text { Silt-clay }\end{array}$ & $\begin{array}{r}7 \\
<1\end{array}$ & $\begin{array}{r}25 \\
9\end{array}$ \\
\hline Winter (Dec-Feb) & 47.78 & 600.3 & 37.5 & $\begin{array}{l}\text { Sand } \\
\text { Silt-clay }\end{array}$ & $\begin{array}{r}8 \\
17\end{array}$ & $\begin{array}{r}16 \\
5\end{array}$ \\
\hline Annual & 515.12 & 6475.1 & 404.9 & $\begin{array}{l}\text { Sand } \\
\text { Silt-clay }\end{array}$ & $\begin{array}{r}6 \\
14\end{array}$ & $\begin{array}{l}11 \\
11\end{array}$ \\
\hline
\end{tabular}


A.

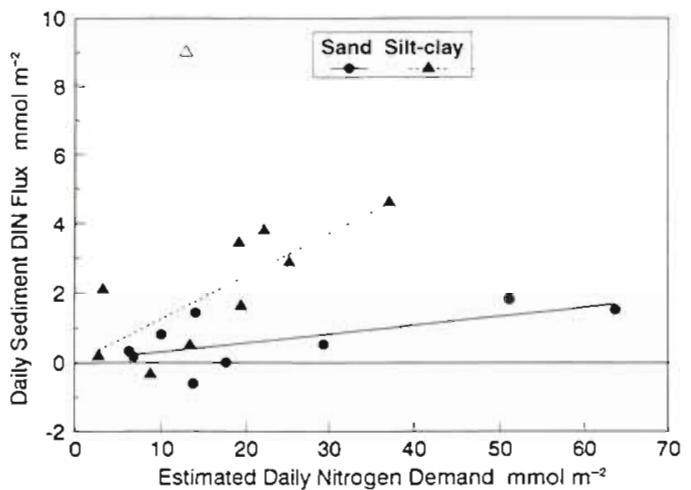

B.

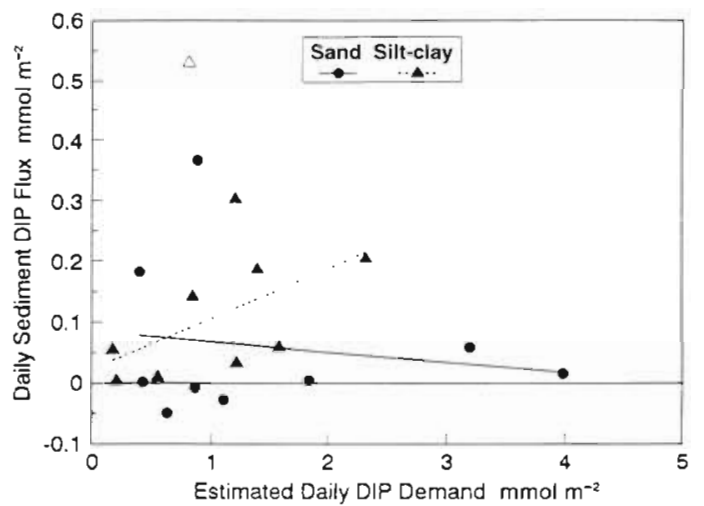

Fig. 8. Daily sediment (A) DIN (sand: $r^{2}=0.43, p=0.05$; siltclay: $r^{2}=0.62, p=0.01$ ) and (B) DIP (sand: $r^{2}=0.03, p=0.68$; silt-clay: $r^{2}=0.31, p=0.12$ ) fluxes versus estimated daily water column inorganic nitrogen and phosphorus demands. (A) Data excluded from analysis due to extreme water turbidity during sampling period

importance of benthic contributions of nutrients to the water column can also be recognized in terms of nutrient turnover time. This was determined by dividing the water column nutrient mass by the daily sediment nutrient flux on a square-meter basis. Short water column DIN and DIP turnover times, on the order of hours, were characteristic for the silt-clay sites during summer, when water column nutrient concentrations were low and sediment nutrient fluxes high. Conversely, nutrient turnover times on the order of days were characteristic of winter conditions, when water column nutrient concentrations were high and sediment nutrient fluxes were low. The sandy sediment sites demonstrated water column nutrient turnover times greater than $1 d$ during the summer and winter sampling seasons.

In summary, results suggest that shallow subtidal ecosystems are of significant importance to carbon and nutrient cycling within the shallow tidal creeks and inlets on the Bay side of the southern Delmarva Peninsula. Sediments were a source of inorganic nitrogen and phosphorus to the water column throughout the year and could supply a significant portion of phytoplankton nutrient assimilation needs. The relative importance of sediments was dependent upon sediment type and season. Benthic community aerobic respiration processes were responsible for a large portion of inorganic nitrogen and phosphorus sediment fluxes for fine-grained sediments as compared to sandy sediment types. The shallowness of these systems allowed for the development of sizable benthic microalgal communities whose influence could reduce nutrient fluxes across the sediment-water interface or assimilate nutrients from the water column. Based on these observations, nutrient budget calculations within these and similar shallow water systems must consider benthicwater column solute exchanges which incorporate sediment type, and photic and aphotic components.

Acknowledgements. The authors thank Luis Lagera. Hartmut Beck and Francisco Gutierrez Mendieta for field assistance and Sherman Stairs of the U.S. National Fish and Wildlife Service for providing field laboratory space. We are also grateful to Roger Buyrn, and Carlton and Annebell Scott for allowing access to the study sites. This manuscript benefited from constructive comments by 3 anonymous reviewers. This research was supported by Virginia's Water Resources Research Center, the Virginia Division of Soil and Water Conservation, and the National Science Foundation.

\section{LITERATURE CITED}

APHA (1989). Standard methods for the examination of water and wastewater, 17th edn. American Public Health Association, Washington, DC

Balzer, W (1984). Organic matter degradation and biogenic element cycling in a nearshore sediment (Kiel Bight). Limnol. Oceanogr. 29(6): 1231-1246

Balzer, W., Grasshoff, K., Dieckmann, P., Haardt, H., Petersohn, U. (1983). Redox turnover at the sediment/water interface studied in a large bell jar system. Oceanol. Acta 6: $337-344$

Boynton, W. R., Kemp, W. M., Osborne, C. G. (1980). Nutrient fluxes across the sediment-water interface in the turbid zone of a coastal plain estuary. In: Kennedy, V. S. (ed.) Estuarine perspectives. Academic Press, New York, p. 93-109

Boynton, W. R., Kemp, W. M., Osborne, C. G., Kaumeyer K. R., Jenkins, M. C. (1981). Influence of water circulation rate on in situ measurements of benthic community respiration. Mar. Biol. 65: 185-190

Callender, E., Hammond, D. E. (1982). Nutnent exchange across the sediment-water interface in the Potomac River estuary. Estuar. coast. Shelf Sci. 15: 395-413

Fisher, T R., Carlson, P. R., Barber, R. T (1982). Sedument nutrient regeneration in three North Carolina estuaries. Estuar. coast. Shelf Sci. 15: 101-116

Flint, R. W., Kamykowski, D. (1984). Benthic nutrient regeneration in south Texas coastal waters. Estuar. coast. Shelf Sci. 18: $221-230$

Folk, R. L. (1980). Petrology of sedimentary rocks. Hemphill Publishing Company, Austin, TX

Garber, J. H. (1987). Benthic-pelagic coupling in the Chesa- 
peake Bay. In: Lynch, M. P., Krome, E. C. (eds.) Perspectives on the Chesapeake Bay: recent advances in estuarine studies. U.S. EPA CBP/TRS16/87. Publication No. 127, Chesapeake Research Consartium, Gloucester Point, VA p. 11-34

Hartwig, E. O. (1976). The impact of nitrogen and phosphorus release from a siliceous sediment on the overlying water In: Wiley, M. (ed.) Estuarine processes; Vol. 1, Uses, stresses, and adaptions to the estuary. Academic Press, New York, p. 103-117

Hill, J. M., Halka, J. (1988). Nutrient regeneration rates in Chesapeake Bay bottom sediments based on bulk properties. In: Lynch, M. P., Krome, E. C. (eds.) Understanding the estuary: advances in Chesapeake Bay research. U.S. EPA CBP/TRS/24/88. Publication No. 29 Chesapeake Research Consortium, Gloucester Point, VA, p. $184-200$

Hopkinson, C. S. (1987). Nutrient regeneration in shallowwater sediments of the estuarine plume region of the nearshore Georgia Bight, USA. Mar. Biol. 94: 127-142

Hopkinson, C. S., Wetzel, R. L. (1982). In situ measurements of nutrient and oxygen fluxes in a coastal marine benthic community. Mar. Ecol. Prog. Ser. 10: 29-35

Jenkins, M. C., Kemp, W. M. (1984). The coupling of nitrification and denitrification in two estuarine sediments. Limnol. Oceanogr. 29(3): 609-619

Joint, I. R. (1978). Microbial production of an estuarine mudflat. Estuar. coast. mar. Sci. 7: 185-195

Kemp, W. M., Boynton, W. R. (1984). Spatial and temporal coupling of nutrient inputs to estuarine primary production: the role of particulate transport and decomposition. Bull. mar. Sci. 35(3): 522-535

Kemp, W. M., Wetzel, R. L., Boynton, W. R., D'Elia, C. F. Stevenson, J. C. (1982). Nitrogen cycling and estuarine interfaces: some current concepts and research directions. In: Kennedy, V. S. (ed.) Estuarine comparisons. Academic Press, New York, p. 209-230

Klump, J. V., Martens, C. S. (1981). Biogeochemical cycling in an organic rich coastal marine basin - II. Nutrient sedi. ment-water exchange processes. Geochim. Cosmochim. Acta 45: 101-121

Murray, L. (1983). Metabolic and structural studies of several temperate seagrass communities, with emphasis on microalgal components. Ph.D. dissertation, College of William and Mary, Williamsburg, VA

NOAA (1990). East coast of North and South America including Greenland tide tables 1991. National Oceanic and Atmospheric Administration, U.S. Department of Commerce, Washington, DC

Parsons, T R., Maita, Y., Lalli, C. M. (1984). A manual of chemical and biological methods for seawater analysis. Pergamon Press, New York

Phoel, W. C., Webb, K. L., D'Elia, C. F. (1981). Inorganic nitrogen regeneration and total oxygen consumption by the sediments at the mouth of the York River, Virginia. In: Neilson, B. J., Cronin, L. E. (eds.) Estuaries and nutrients. Humana Press, Clifton, NJ, p. 607-618

Pinckney, J., Zingmark, R. G. (1993). Biomass and production of benthic microalgal communities in estuarine habitats. Estuaries 16(4): 887-897

Propp, M. V., Tarasoff, V G., Cherbadgi, I. I., Lootzik, L. V. (1980). Benthic-pelagic oxygen and nutrient exchange in a coastal region of the Sea of Japan. In: Tenore, K. R., Coull, B. C. (eds.) Marine benthic dynamics. University of South Carolina Press, Columbia, p. 265-284

Reay, W. G, Gallagher, D. L., Simmons, G. M. Jr (1992a). Estuarine sediment nutrient exchanges: the importance of physical transport mechanisms and benthic micro-communities. In: Stanford, J., Simons, J. (eds.) Proceedings of the first international conference on groundwater ecology. American Water Resources Association, Bethesda, MD, p. $217-229$

Reay, W. G., Gallagher, D. L., Simmons, G. M. Jr (1992b) Groundwater discharge and its impact on surface water quality in a Chesapeake Bay inlet. Wat. Resour. Bull. 28(6): $1121-1134$

Redfield, A. C., Ketchum, B. H., Richards, F. A. (1963). The influence of organisms on the composition of seawater. In Hill, M. N. (ed.) The sea, Vol. 2. Wiley-Interscience, New York, p. $26-77$

Riznyk, R. Z., Phinney, H. K. (1972). Manometric assessment of interstitial microalgae production in two estuarine sediments. Oecologia 10: 193-203

Rizzo, W. M. (1986). Community metabolism and nutrient dynamics of a shoal sediment in a temperate estuary, with special emphasis on scales of temporal variability. Ph.D. dissertation, College of William and Mary, Williamsburg, VA

Rizzo, W. M. (1990). Nutrient exchanges between the water column and a subtidal benthic microalgal community Estuaries 13(3): 219-226

Rowe, G. T., Clifford, C. H., Smith, K. L. (1977). Nutrient regeneration in sediments off Cap Blanc, Spanish Sahara Deep Sea Res. 24: 57-63

Rowe, G. T., Clifford, C. H., Smith, K. L., Hamilton, P. L (1975). Benthic nutrient regeneration and its coupling to primary productivity in coastal waters. Nature 255: $215-217$

Simmons, G. M. Jr, Miles, E., Reay, W. G., Gallagher, D. L. (1992). Submarine groundwater discharge quality in relation to land use patterns in the southern Chesapeake Bay. In: Stanford, J., Simons, J. (eds.) Proceedings of the first international conference on groundwater ecology. American Water Resources Association, Bethesda, MD, p $341-350$

Simon, N. S. (1988). Nitrogen cycling between sediment and the shallow-water column in the transition zone of the Potomac River and estuary. I. Nitrate and ammonium fluxes. Estuar. coast. Shelf Sci. 26: 483-497

Strickland, J. D. H., Parsons, T. R. (1972). A practical handbook of seawater analysis, 2nd edn. Bull. Fish. Res. Bd Can. 167

Teague, K. G., Madden, C. J., Day, J W. (1988), Sedimentwater oxygen and nutrient fluxes in a river-dominated estuary. Estuaries 11(1): 1-9

The World Almanac (1990/1991). Pharos Books, New York

Thomann, R. V., Mueller, J. A. (1987). Principles of surface water quality modeling and control. Harper and Row, New York

Twilley, R. R., Kemp, W. M. (1987). Estimates of sediment denitrification and its influence on the fate of nitrogen in Chesapeake Bay. U.S. EPA Chesapeake Bay Program CBP/TRS1/87, Annapolis, MD

U.S. EPA (1983). Methods for chemical analysis of water and wastes. EPA-600/4-79-020. U.S. Environmental Protection Agency, Cincinnati

Wetzel, R. G., Likens, G. E. (1991). Limnological analyses, 2nd edn. Springer-Verlag, New York

Zar, J. H. (1984). Biostatistical analysis, 2nd edn. PrenticeHall, lnc., Englewood Cliffs, NJ

Zeitzschel, B. (1979). Sediment-water interaction in nutrient dynamics. In: Tenore, K. R., Coull, B. C. (eds.) Marine benthic dynamics. Univ. of South Carolina Press, Columbia, $p$. $195-218$ 